of 1978, teaching history and linguistics at the University of Zambia from 1973. There he established loyal, very productive, life-long relationships with colleagues, students, and friends and became an unrelenting critic of the authoritarian, sometimes brutal, Banda regime in Malawi. An extraordinary sympathetic discernment, a discerning sympathy, drove the well-known, widely admired series of chapters and articles that appeared then on the processes of colonialism, which he dissected as "the making of an imperial slum" in the case of the Nyasaland railways, as ecological degradation in eastern Zambia, in agrarian history as hunger, and especially as the pervasive inhumanity of the chartered "prazo" companies in Portuguese Mozambique. With Landeg White, he evoked Capitalism and Colonialism in Mozambique , the title of the jointly authorized monograph published in 1981, as Africans experienced them. This major study, characterized by Malyn Newitt in a subsequent survey of Mozambique as "the outstanding book on the country's history," culminated this phase of his engagement with Africa and Africans by presenting the voices of peasant women who sang their laments at being forced to grow cotton to the detriment of their ability to feed their families. Ongoing theoretical currency always pervaded Leroy's work, but beneath the abstractions was his characteristic ability to write rigorously empirical history, always with a heart. As one of Leroy's students, Chipasha Luchembe, put it: he understood and conveyed the responsible sense of "poetic license."

Leroy returned to the United States to take a visiting appointment at the University of Virginia in 1978 and stayed to settle more or less into Charlottesville until 1983, with succeeding appointments through the Carter G. Woodson Institute for Afro-American and African Studies, interspersed with peripatetic teaching at UCLA and Ohio University and a fellowship at Yale's Southern African Research Program (1981-82). It was in Virginia that I leaned most heavily on his ability to draw clear insight out of formative intellectual muddle, as well as coming to know Patricia and working with her professionally, and appreciating their teamwork over long evenings of good food and warm conviviality, as illuminated by the wide-ranging conversation as by the light gardens filled with orchids and violets. From Leroy's friends in Africa and Europe and North America, I know that I was far from alone in savoring his (their!) delicious blending of flavors, flowers, and friendship.

While enriching the African studies centers of North America in the early 1980s, Leroy pursued, in continuing collaboration with Lan White, the potential of fusing socialscience analysis with humanistic sensibility, in the memorably distinctive style in which these two complemented one another so productively. Before leaving Charlottesville in 1983 , almost in passing, Leroy convened the leading historians and anthropologists of southern Africa to launch the project that became The Creation of Tribalism in Southern Africa (1988) -- a book that has become a landmark collection on the historicization of ethnicity.

Upon returning to the Boston area in 1984 as a visitor at Harvard, he remained to complete his major works as Professor of African History from 1990. At Harvard, he was known for his dedication to students in all fields, convened two major international conferences, and chaired the Harvard Committee on African Studies from 1990 to 95.

With Lan, Leroy revealed the political thrust of oral arts throughout southern and central Africa, provocatively evoking the deep continuities as well as the wrenching changes in modern southern Africa, in Power and the Praise Poem: Southern African Voices in History, which appeared in 1991. This intellectual collaboration between partners thrived on Leroy's ability to draw as fruitfully on close relationships with others as his own independence of spirit stimulated those around him to thrive as well. Working with Leroy, colleagues and students remember well, was not always so comfortable but, with his direct (not to say acerbic!) challenges consistently softened by wry wit and a twinkle in the eye, always worth the acknowledgment that, in listening to you, he heard things you hadn't thought of.

Nearing what turned out to be the end of his career, Leroy followed his love of Africa and of language back to Bantu linguistics. At his death, he had all but completed his edition of an English-Lakeside Tonga dictionary, a historically erudite compilation of some 15,000 words recorded more than a century ago by another of the founders of the Livingstonia Mission, Rev. Alexander G. McAlpine. Still growing in multi-talented, multi-faceted character, he was in Togo laying the groundwork for future historical research on ethnogenesis in a region of the continent entirely new to him, when his lymphoma abruptly took him out of Africa for the last time. We will not have the full development of Leroy's thinking on spirit possession in Malawi and Zambia, which he had planned in a work on Spirits, Women, and Deprivation, or fully appreciate his awareness of style and expression in language and history, in a projected Ideophones as Stylistic Devices in Tumbuka. But the accents in his professional plans - spirit, sensitivity to gender, empathy for deprivation, and unfailing style - might also have been his personal epitaph.

Leroy's students remember him, beyond his wise intellectual guidance through fields ranging far beyond those in which he pub- lished, for the devotion he brought to each of them through his teaching in Malawi, in Zambia, and in South Africa, as well as in Virginia, California, Ohio, and especially Massachusetts. His engaging wit initiated believers and doubters alike into multiple aspects of African history, in all its interdisciplinary wholeness. As he revealed the human costs of colonial "development" in Africa, he supported the intellectual development of his students with no-nonsense devotion to their personal growth and welfare, in which Patricia joined, to their delight and appreciation. This generous, wise, very private personality infused an accomplished public professional presence in paradoxically open ways.

Those who knew Leroy's ability to nurture luxuriant violets and orchids and gardens in challenging climates, tropical as well as temperate, understood the integrity of character that made everyone, and every thing, around him flourish. Wherever in the world we knew him, we knew the same man. He is physically removed from us now, but he leaves huge personal and professional legacies. His thorough research and rigorous method imbued his work with the power of sheer substantiality, and he wielded theory with authority but not pretension. Even with his career cut short in the prime of his creativity, he had repeatedly honed the cutting edges of what later became major sub-fields of African studies: beyond linguistics, in corporate colonialism, environmental history, hunger and poverty, women's voices, literary and political analysis of oral performance, subjugated knowledges, and the historicity of ethnic community.

Just as Leroy kept on moving on to open fresh fields of inquiry, leaving others inspired to develop the several he had been among the first to plough, so he has now left us all empowered to carry on again. We are grateful, and will miss him. [Website: www.AfricaBib.Org.1999]

\section{Scott Kloeck-Jenson (1965-1999)}

\section{Prepared by Anne Pitcher of Colgate University}

Friends, relatives, and colleagues were shocked and saddened by the tragic deaths of Scott Kloeck-Jenson, his wife, Barbara and their two children Zoe and Noah in a car accident in South Africa on June 23, 1999. Scott was the Project Director in Mozambique for the University of Wisconsin-Madison's Land Tenure Center and he was also working on a doctoral dissertation based on research in 
Zambezia Province, Mozambique at the time of his death. He and his family were active, joyous participants in various communities in Maputo and they will be greatly missed.

Scott was born in Minnesota in 1965 and received his B.A. from St. Olaf College in Northfield, Minnesota in 1987. After two years with the Peace Corps in Lesotho where he met his wife, Barbara, Scott obtained a Master's degree in Political Science from the University of Wisconsin-Madison in 1993. Awarded Fulbright and MacArthur scholarships for doctoral research, Scott and his family then traveled to Mozambique so that he could undertake fieldwork in Zambezia province for his dissertation. The ease with which he fit into Mozambican society and his considerable intellectual ability caught the attention of the Land Tenure Center at Wisconsin-Madison. Before he even finished his thesis, he was appointed their Project Director for Mozambique, a position he occupied for the past two years. He was due to return to the United States in January 2000 to complete his dissertation in Political Science at the University of Wisconsin-Madison.

As Resident Project Director for the Land Tenure Center, Scott was responsible for coordinating a number of research projects on land use and development, and he participated also in official policy debates on the land question. His real gift was that he championed the rights of local communities to participate in decisions affecting the use of land and tree tenure but without underestimating the complexities of defining what a local community was, who belonged to it, and how it could be addressed in legislation. He wrestled constantly and thoughtfully with the issues affecting the use of resources in Mozambique as evidenced by his series of policy statements and position papers addressing forest resources, tree tenure, and land law.

His sensitivity to the various concerns of diverse actors in the land debate is evidenced by the broad spectrum of people who spoke at a memorial service for him held at the Ministry of Agriculture and Fisheries in Mozambique. He was mourned not only by the Minister of Agriculture and Fisheries who noted how well Scott understood Mozambique's agrarian challenges but also by the National Union of Peasants' Associations who praised his sincere identification with the issues that most affected rural peoples. As David Tschirley of Michigan State University noted, "When people talk about Scott in Portuguese, they frequently use the term "simpatia". It translates into English as "regard", but it implies a deeper level of emotional identification than that. Even in his professional work, Scott affected people in Mozambique on an emotional level. He combined intelligence, real competence, kindness and concern, a wonderful sense of humor, and lack of self importance in a way that lead people to develop a great regard for him. Not many people in life bring all those qualities to what they do and what they are."

At the Universidade Eduardo Mondlane where the Land Tenure Center was based, Scott also collaborated with his Mozambican counterpart, the Nucleus of Land Studies, to train Mozambican students and scholars in the study, research, and promotion of landrelated issues in the country. With the aid of Mozambicans, he expanded and made accessible to both nationals and foreigners an extremely well-organized library that really ought to bear his name in perpetuity. He was completely unselfish about sharing research ideas and references and he encouraged others to do the same.

Anyone who met Scott was impressed with his extensive knowledge of Mozambique, his genuine passion for ideas, and his innate sense of fairness. Although he displayed a solid grasp of development theory, he eschewed abstract models in favor of an eclectic and innovative blending of detailed fieldwork combined with relevant theoretical contributions from political science, anthropology, and history. Doing fieldwork with him in Zambezia Province, northern Mozambique in 1998, I marveled at how patiently and carefully he conducted interviews with small holders, slowly eliciting from them their life stories without any sense of wanting to rush onto the next family. He appreciated and positively valued qualitative approaches and didn't hesitate to spend hours or days with one family, or to stray from his questionnaire if he thought he would learn something new. If he had to walk through stagnant water or drink the local brew in order to pay his respects to a village notable, then he would do it, with a great deal of humor and grace. All of these things made him a dedicated researcher, an engaging intellectual, a gifted conversationalist, and a promising scholar.

In every sense Scott was a whole person. He balanced his professional life with a totally full family life. No one who ever visited the Kloeck-Jensons at their home in Maputo will forget the pictures of Scott and Barbara's wedding, or the dozens of photos in every room chronicling the big and small occasions in the children's lives, from Zoe reading one of her favorite books to Noah taking a bath. The kids, ages 5 and 2, spent most of their lives in Mozambique and were as much Mozambican as they were American. Relatives of the Kloeck-Jensons, friends of the family in Mozambique and the US, and Scott's colleagues all feel greatly their loss. But we shall draw inspiration from their graciousness and the dignified way they treated people. We hope to remember them through Scott's writings and the creation of several scholarship funds in their names.

\section{EDITORIAL NOTE:}

The deadline for submissions to the October/December 1999 issue of ASA NEWS has been extended to October 1, 1999. Please send items for publication via email to: callasa@rci.rutgers.edu. The editorial team is grateful to the Michigan State University Tuesday Bulletin for its contributions to this issue.

For information about advertising in the newsletter, contact the ASA office.

\section{ANNOUNCEMENTS}

\section{New Website}

AfricaBib is pleased to announce the opening of its new website. It was created as a way to freely disseminate information from two African studies databases as well as information on Africa from other sources. The site presently contains the Africana Periodical Literature Bibliographic database. This work was originally started in 1974 as an effort to index all the issues of each periodical/journal title and collect them in one source. The website also includes the Africana Women's Database which indexes materials published in English about African Women. If you know of any materials that are not in the index and deserve to be included, or have questions or comments, please contact: Davis Bullwinkle, Telephone: (501) 569-8521; Email: dabullwinkle@ualr.edu.

\section{Membership Invitation}

The National Coalition of Independent Scholars (NCIS), an affiliate of the American Council of Learned Societies, invites members to become a part of a supportive international network of colleagues committed to independent scholarship. Members receive a subscription to the Independent Scholar, participate in national and regional conferences for independent scholars, and join discussions on the H-Scholar listserv. For more information, contact: NCIS, P.O. Box 5743, Berkeley, CA 94705; Telephone: (510) 540-8415; Website: www.ncis.org.

\section{SSRC Chooses New President}

The Social Science Research Council (SSRC) announces that Craig Calhoun, Professor of Sociology and History and Chair of the Sociology Department at New York University, will be its new president. The 